\title{
Accessible Worldwide - and Higher Ambitions
}

This is the first Open Access issue of Arctic Review on Law and Politics, a milestone for the journal - and one that hopefully can form a pattern for how research results and new knowledge can be communicated effectively within the social sciences and jurisprudence.

It is now 5 years since Arctic Review on Law and Politics was launched. The intention of the journal, born in April 2010, was to "provide new insights and a deeper understanding of fundamental issues related to the Arctic and the High North" by presenting peer-reviewed articles, as stated boldly in the journal's first editorial. This goal should be achieved by, among others things, publishing topics on resource management, fishery issues, environmental questions, law of the sea and rights of indigenous people - and thereby be a forum for academic discussion on sustainable development in the North.

I am pleased to say that the goal that was staked out an early spring day a year before the journal was born has largely been met. Not only is the journal accessible worldwide, in its first 5 years more than 50 peer-reviewed articles of the kind announced in 2010 have been published, based on contributions not only from Scandinavia, but also from Canada, Russia, New Zealand, the USA and the EU; all have undergone thorough double-blind peer reviews. In addition, Arctic Review has also become a widely used channel for publishing articles on indigenous people's rights and issues.

These achievements have been noticed by the law faculties in Norway, which have nominated Arctic Review for level two status. This is the highest ranking an academic journal or publisher can reach in Norway and is limited to those that are leading in a broad professional setting and not constituting more than $20 \%$ of total scientific publications in its field. The nomination was followed up by The Norwegian Association of Higher Education Institutions (UHR), which in December 2014 approved Arctic Review on Law and Politics at level two, effective January 1, 2016. Along with the journal's new publisher, NOASP/Cappelen Damm Akademisk in collaboration with Co-Action Publishing, the editors will ensure that neither the nominators, UHR nor our readers will be disappointed by the level two adoption in the coming years.

In this issue, we are pleased to present four articles expounding on issues from the Arctic and the High North, including the livelihood of the indigenous Sámi. The rich fishery resources off the coast of Finnmark have historically attracted fishermen both from other parts of Norway and from the neighboring countries. In "Russian Fishing 
Activities off the Coast of Finnmark," Kirsti Strom Bull elaborates on the legal history of the neighboring country's fishing outside Finnmark until its termination in the early 1900s, showing that Russian fishermen, like Sámi from Finland - and unlike fishermen from other nations - were authorized to establish shacks and landing places in Finnmark.

Due to the growing global demand for minerals, extractive industries are continuously expanding. Together with other interventions in the pastures and environmental problems caused by climate changes, this poses a real threat to the traditional livelihoods of the Sámi people. In the research project Sustainable Mining, local communities and environmental regulation in the Kolarctic area (SUMILCERE), based on an exemplary multilateral research, Timo Koivurova, Vladimir Masloboev, Kamrul Hossain, Vigdis Nygaard, Anna Petrétei and Svetlana Vinogradova analyze how the four countries with an indigenous Sámi population aim to protect the Sámi culture against adverse impacts of mining via relevant national legislation. Their analyses have resulted in an extensive and thoughtful article titled "Legal Protection of Sami Traditional Livelihoods from the Adverse Impacts of Mining," which clarifies similarities and differences in how Finland, Norway, Sweden and Russia legally seek to ensure Sami coexistence with the extractive industries.

The salmon stocks of the Deatnu River, which forms the border between Norway and Finland flowing through the core area of the Sámi, are considered critically endangered. In "One Valley, Three Hands," Aike Niillas Peder Selfors explores how international laws protecting Sami culture and livelihood are to be applied when Finland and Norway adopt new principles aiming to regulate salmon fishing in the border river. The author questions the ongoing negotiations and asks if they have already violated the rights protecting the Sami people.

In "The EU Seal Products Ban - Why Ineffective Animal Welfare Protection Cannot Justify Trade Restrictions under European and International Trade Law," Martin Henning explores the legitimacy of the general ban on trade in seal products adopted by the European Union. The author analyzes the current ineffective EU ban on seal products, arguing that it has a weakly founded legal basis in EU treaties and should therefore be considered annulled.

We are honored to present all these interesting explorations in arctic law. Pleasant reading.

Oyvind Ravna

Editor-in-chief 